\title{
SELECTED WAYS OF NONVEBRAL COMMUNICATION IN UNIVERSITY EDUCATION
}

\section{[VYBRANE SPOSOBY NEVERBALNEJ KOMUNIKACIE VO VYSOKOSKOLSKEJ EDUKACII]}

\author{
Veronika Michvocikova
}

doi: 10.18355/PG.2022.11.1.8

\begin{abstract}
The presented study has a theoretical-empirical character. The theoretical part of the study defines the basic theoretical characteristics of pedagogical communication. Subsequently, there is a detailed theoretical analysis of nonverbal communication and its application to the university educational process. Theoretical definitions and characteristics are used as a background for the empirical research of the mentioned issue. There is empirical research of non-verbal communication in the university educational process in the empirical part of the study. Data collection was realized by the prepared questionnaire. Empirical research has a quantitative design of research. The analysis of the collected data was realized by the results of bivariate and univariate data analysis in the statistical software SPSS 20. The main aim of the study is the analysis of the haptic area in the non-verbal communication used by a university teacher in the university educational process.
\end{abstract}

\section{Key words}

Educational process, nonverbal communication, pedagogical communication, university education, university students

\section{Anotácia}

Predkladaná štúdia je teoreticko-empirického charakteru. Teoretická čast' štúdie je zameraná na vymedzenie základných teoretických charakteristík pedagogickej komunikácie. Podrobnejšia teoretická analýza sa následne sústred’uje na základné definovanie neverbálnej komunikácie aplikovanej do vysokoškolského edukačného procesu. Na uvedené teoretické východiská plynule nadväzuje empirické skúmanie uvedenej problematiky. Empirická čast' štúdie pozostáva $\mathrm{z}$ analýzy a interpretácie výsledkov vlastného empirického skúmania problematiky neverbálnej pedagogickej komunikácie vo vysokoškolskom edukačnom procese. Získavanie údajov potrebných pre analyzovanie stanovenej oblasti prebiehalo prostredníctvom vopred pripraveného dotazníka. Využitý bol kvantitatívny dizajn skúmania. Následná interpretácia získaných údajov bola zrealizovaná na základe bivariačnej a multivariačnej analýzy údajov v štatistickom softvéri SPSS 20. Hlavným ciel’om predkladanej štúdie je analýza vybranej oblasti haptiky ako jednej zo súčastí neverbálnej komunikácie využívanej vysokoškolských učitel'om vo vysokoškolskom edukačnom procese. 


\section{Kl'účové slová}

Edukačný proces, neverbálna komunikácia, pedagogická komunikácia, vysokoškolská edukácia, vysokoškolskí študenti

\section{Úvod}

Za jednu z najvýznamnejších profesií $\mathrm{v}$ spoločenskom systéme môžeme považovat' bez najmenších pochybností učitel'skú profesiu. Vedenie a smerovanie procesov výchovy a vzdelávania odborníkom - učitel’om $\mathrm{v}$ inštitucionalizovanom prostredí školy predstavuje náročný proces. Pedagóga možno považovat' za odborníka, ktorý disponuje širokým spektrom vlastností nevyhnutných pre realizáciu profesie učitel'a. Vedenie edukačného procesu si okrem iného vyžaduje, aby pedagóg dokázal vhodne, a zároveň efektívne komunikovat' s osobami participujúcimi na procesoch výchovy a vzdelávania, a to na rôznych úrovniach existujúceho školského vzdelávacieho systému. V tejto súvislosti chceme sústredit' centrum pozornosti podrobnejšieho skúmania $\mathrm{k}$ priebehu edukačného procesu na vysokých školách. Proces edukácie v prostredí vysokej školy prebieha špecifickým spôsobom. Za rovnako špecifický možno vymedzit' aj priebeh a spôsob pedagogickej komunikácie vo vysokoškolskom edukačnom procese. Vysokoškolský pedagóg komunikuje s vysokoškolskými študentmi prostredníctvom verbálneho, ale aj neverbálneho spôsobu. Dôležitými sa preto stávajú nielen využívané slovné výrazové prostriedky adresované vychovávaným a vzdelávaným osobám. Odborný výklad obsahu vzdelávania je taktiež dopíñaný aj neodmyslitel'ným mimoslovným spôsobom, na základe ktorého môžu vysokoškolskí študenti identifikovat' najmä subjektívny prístup vysokoškolského pedagóga $\mathrm{k}$ realizácii výchovno-vzdelávaciemu procesu v prostredí vysokej školy. Preto je podla nášho názoru potrebné venovat' zvýšenú pozornost' skúmaniu priebehu uskutočňovania pedagogickej komunikácie vo vysokoškolskom edukačnom procese. Ked’že však považujeme problematiku pedagogickej komunikácie vo všeobecnosti za vel'mi rozsiahlu, tak v rámci zamerania predkladanej štúdie smerujeme naše analýzy na neverbálnu komunikáciu a na jednotlivé spôsoby realizovania neverbálnej pedagogickej komunikácie vo vysokoškolskom edukačnom procese. Neverbálna komunikácia vysokoškolského pedagóga dotvára celkové ponímanie vysokoškolského edukačného procesu u vysokoškolských študentov. V intenciách uvedeného považujeme za dôležité približenie zvolenej oblasti neverbálnej komunikácie - oblasti haptiky vo vysokoškolskej edukácii z pohladu oslovených vysokoškolských študentov.

\section{Pedagogická komunikácia v edukačnom procese}

Edukačný proces sa vyznačuje mnohými špecifickými charakteristikami. Ak chceme podrobnejšie skúmat' podstatu výchovy a vzdelávania predovšetkým v prostredí školy, je podl'a nášho názoru nutné zaoberat' sa predpokladmi vedúcimi $\mathrm{k}$ uskutočňovaniu uvedeného procesu. Za jednu $\mathrm{z}$ nevyhnutných podmienok, a aj predpokladov edukácie považujeme interakciu medzi edukátorom a edukantom. Ked’že hovoríme o interakcii medzi l'udskými jedincami, tak jej priebeh je spravidla založený na vzájomnom porozumení vyplývajúcom z dorozumievania sa uvedenými zainteresovanými stranami. 
Dorozumievanie sa medzi l’udskými jedincami prebieha najčastejšie prostredníctvom komunikácie. Komunikáciu využívanú v edukačnom procese charakterizujeme ako pedagogická komunikácia. Pedagogickou komunikáciou označujeme špeciálnu formu sociálnej komunikácie (Tomková, 2010). Sociálna komunikácia sa dotýka interakcií medzi jednotlivcami a spomenutým výrazom „označujeme prijímanie a odovzdávanie informácií v sociálnom styku“ (Hasajová - Porubčanová Bilč́k, 2020, p. 10). Z toho vyplýva, že realizácia pedagogickej komunikácie je založená na prebiehajúcich interakciách medzi participantmi edukačného procesu v prostredí školy. Kontakt učitel’a s vychovávanými a vzdelávanými osobami V školskom prostredí môžeme bez najmenších pochybností považovat' za sociálny styk, prostredníctvom ktorého dochádza $\mathrm{k}$ odovzdávaniu, ako aj k prijímaniu informácii širokého spektra. Gavora (2005, p. 25) rozlišuje v rámci pedagogickej komunikácie sprostredkovanie informácii jazykovými a nejazykovými prostriedkami. Na základe uvedeného považujeme za dôležité odlišovanie pedagogickej komunikácie realizovanej slovným - verbálnym spôsobom. Uvedený typ komunikácie je založený na využívaní jazykových výrazových prostriedkov. Okrem toho nezabúdame v edukačnom procese zdôraznit' ani uskutočňovanie komunikácie, ktorá sa nerealizuje prostredníctvom jazykových výrazových prostriedkov. Hovoríme o mimoslovnej - neverbálnej komunikácii.

Ak sa sústredíme na skúmanie edukačného procesu v školskom prostredí, tak komunikácia spravidla prebieha troma smermi (Samuhelová, 1989 in Kormanovičová - Haláková, 2010):

1) Dialóg - obojstranná komunikácia medzi učitel'om a jedným žiakom (42\% výskytu)

2) Jednosmerná komunikácia učitel’a k triede - ako príklad možno uviest' sprístupňovanie nového učiva (30\% výskytu)

3) Jednosmerná komunikácia učitel’a $\mathrm{k}$ jednému žiakovi - príkladom môže byt' zadávanie konkrétnych pokynov (10\% výskytu).

Smer priebehu komunikácie $\mathrm{v}$ edukačnom procese $\mathrm{v}$ prostredí školy závisí spravidla od konkrétnej situácie. Podla nášho názoru je nutné preferovat' obojstrannú komunikáciu medzi učitel'om a žiakom. Uvedené konštatovanie sa dotýka všetkých úrovní výchovno-vzdelávacieho procesu. Spoločný dialóg učitel'a s vychovávanou a vzdelávanou osobou však považujeme za nevyhnutnost' predovšetkým pri vysokoškolskom edukačnom procese. „V podmienkach vysokých škôl je komunikácia o to dôležitejšia, lebo je realizovaná $\mathrm{v}$ rovine spoločného odborného zamerania vysokoškolských učitel'ov a študentov s cielom odovzdávania poznatkov a ich prijímania“" (Danek, 2014, p. 24). Pedagogickú komunikáciu vo vysokoškolskom edukačnom procese vnímame ako proces, prostredníctvom ktorého dochádza $\mathrm{k}$ odovzdávaniu rozmanitých informácii vysokoškolským učitel’om smerom $\mathrm{k}$ percipientom - vysokoškolským študentom. Zároveň však musíme dodat', že vysokoškolskí študenti nepredstavujú iba pasívnych prijímatel’ov množstva komunikovaných informácií. Okrem toho, že dokážu postupne samostatne uvažovat' o prezentovanom obsahu 
vzdelávania, rovnako vnímajú aj celkový spôsob prezentovania informácií vysokoškolským pedagógom. V súvislosti s rolou učitel’a v pedagogickej komunikácii počas priebehu edukačného procesu môžeme doplnit', že ,učitel' je taký subjekt edukačného procesu, ktorého činnost' je prioritne zacielená na transmisiu poznatkov k príjemcom žiakom, a z toho nutne vyplýva jeho vysoká aktivita $\mathrm{v}$ komunikácii pri vyučovaní“" (Průcha, 2013, p. 27). Vysokú aktivitu pedagóga v pedagogickej komunikácii možno predpokladat' v slovnom, ako aj v mimoslovnom komunikovaní.

Z hl'adiska zamerania nášho skúmania sústred'ujeme pozornost' k vymedzeniu neverbálnej komunikácie tvoriacej neoddelitel'nú súčast' pedagogickej komunikácie aj vo vysokoškolskom edukačnom procese.

\section{Neverbálna komunikácia}

Podrobnejším skúmaním oblasti pedagogickej komunikácie sa zameriavame na detailnejšie charakterizovanie neverbálnej komunikácie. „Neverbálna komunikácia je dôležitým komponentom verbálnej komunikácie. Podiela sa na úspešnom priebehu verbálnej komunikácie, a prispieva k efektínnej komunikácii tým, že jej obsah dopíňa dôležitými fonickými, vizuálnymi a kinetickými signálmi, a tak pomáha rozumiet' hovorenému slovu a pochopit' zámery komunikujúcich" (Klincková, 2011, p. 9). Tak ako sme už uviedli vyššie, proces komunikácie je možné realizovat' verbálnym, ako aj neverbálnym spôsobom. V tejto súvislosti rovnako zdôrazňujeme, že uvedené spôsoby realizácie procesu komunikácie sa navzájom prelínajú a doplńajú. K prelínaniu a dopínaniu prvkov verbálnej a neverbálnej komunikácie dochádza aj pri uplatňovaní rôznych metód a prostriedkov využívaných aj vo vysokoškolskom edukačnom procese. Preto komunikácia zastáva dôležité postavenie vo výchovno-vzdelávacom procese na uvedenej úrovni vzdelávacieho systému (Danek, 2014, p. 108).

Opätovným zameraním našich analýz $\mathrm{v}$ súvislosti $\mathrm{s}$ problematikou neverbálnej komunikácie chceme poukázat' na niekol'ko možností mimoslovného komunikovania. Najčastejšie rozlišujeme osem druhov neverbálnej komunikácie, ktoré sa vzájomne doplñajú a prelínajú (Kormanovičová - Haláková, 2008, p. 59):

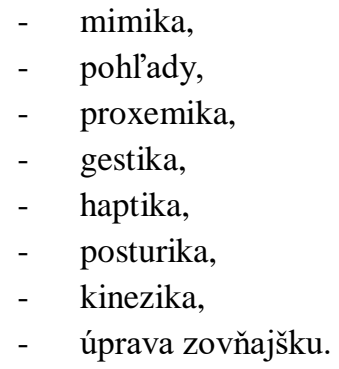

Priebeh a rozsah konkrétneho spôsobu mimoslovného komunikovania je u každého l'udského jedinca jedinečný. Prevaha niektorého z uvedených druhov v neverbálnej komunikácii je ovplyvnená konkrétnym situačným 
kontextom prebiehajúcej komunikácie, ako osobnostnými vlastnost’ami a charakteristikami komunikujúcich.

Špecifikovaním d'alšieho analyzovania vyššie uvedenej oblasti smerujeme centrum pozornosti k vymedzeniu oblasti haptiky.

\section{Haptika ako súčast' neverbálnej komunikácie}

Na základe identifikovania niekol'kých spôsobov neverbálnej komunikácie považujeme za potrebné podrobnejšie vymedzit' súčast' neverbálnej komunikácie označovanú ako haptika. Haptika je „disciplína, ktorá sa zaberá skúmaním dotykov, gr. haptein - dotýkat' sa, tzv. taktilný kontakt dotyk.“ (Hasajová-Porubčanová-Bilč́́k, 2020, s. 129). Rovnako môžeme doplnit, že neverbálna komunikácia realizovaná prostredníctvom dotykov je vel'mi účinná, pretože dokáže odovzdat' množstvo informácií a signálov o pocitoch, postojoch, myšlienkach a motiváciách človeka. Vnímat', interpretovat' a správne pochopit' signály haptiky je zložitejšie ako pri verbálnom prejave (Nosková, 2019, s. 50). Dotyky uskutočňované počas interakcie s druhými jedincami charakterizujeme ako nezanedbatel'ný indikátor rôznych pocitov rovnako komunikátora, ako aj u komunikanta. Podrobnejšiu analýzu smerovania dotykov v komunikačnom procese však považujeme za zložitý proces smerujúci $\mathrm{k}$ skúmaniu a k následnému identifikovaniu subjektívneho vnímania konkrétnej komunikačnej situácie $\mathrm{u}$ jedinca.

Klincková (2011, s. 48) rozlišuje v komunikácii využívanie troch druhov dotykov:

1) dotyk osoby,

2) dotyk predmetu,

3) dotyk seba samého.

Charakterizovaním pedagogickej komunikácie $\mathrm{v}$ školskom prostredí chceme skonštatovat', že zo strany pedagóga je podl'a nášho názoru možné zaznamenat' najmä dotyky predmetov alebo dotyky seba samého. Predpoklad pre empirické skúmanie stanovenej problematiky predstavuje upozornenie na spôsoby dotýkania sa vlastného tela počas priebehu komunikačného procesu. Najčastejšie je možné sledovat' nasledujúce spôsoby dotýkania sa vlastných častí tela počas realizácie komunikačného procesu (Peas 1897 in Nosková, 2019, s. 50):

- dotyky tváre: nervozita, stres, smútok (utieranie síz);

- Súchanie nosa: klamstvo, podvod, konflikt;

- dotyky čela: premýšl’anie, dumanie

- dotyky očí, šúchanie očí: únava, pret’aženie, prebudenie

- dotyky uší: intenzívny stres;

- brada v dlaniach: hlboké zamyslenie, starosti, smútok;

- dotyky vlasov: nervozita, ale aj zvádzanie či zlozvyk;

- t'ahanie vlasov, šklbanie vlasov: zúfalstvo, hnev, zlost', intenzívny stres;

- hladkanie vlasov: láskanie, obdiv, upokojenie. 
Spôsoby dotýkania sa jednotlivých častí vlastného tela spravidla indikujú niekol'ko vyššie uvedených subjektívnych pocitov u komunikujúcich. Ide o viditel'né prejavy správania sa jedinca, a preto je možná aj ich aplikácia do pedagogickej komunikácie počas vysokoškolského edukačného procesu. Vysokoškolský pedagóg vyjadruje dotýkaním sa predovšetkým oblasti svojej tváre svoje vlastné subjektívne pocity odzrkadl'ujúce aktuálne prežívanie odovzdávania rozmanitých informácií vysokoškolským študentom. Tak ako aj pri ostatných prejavoch neverbálneho spôsobu komunikovania, dotyky seba samého sú pozorovatel'né prijímatel'mi komunikovaného obsahu.

\section{Materiál a metodika}

Ked’že považujeme oblast' dotykov počas priebehu komunikačného procesu za neoddelitel'nú súčast' neverbálnej komunikácie realizovanej vo vysokoškolskom edukačnom procese, tak za hlavný ciel' nášho empirického skúmania považujeme zistenie výskytu vybranej oblasti haptiky u vysokoškolských pedagógov v závislosti od pohlavia. Za vybranú oblast' haptiky sme na základe vyšších teoretických analýz zvolili dotyky seba samého u vysokoškolského pedagóga uskutočňované voblasti tváre. Konkrétne sme skúmali dotyky vlasov a prípadnú podmienenost' uvedeného spôsobu neverbálnej komunikácie pohlavím vysokoškolského pedagóga. Uvedené otázky boli predmetom zistovania u oslovenej skupiny vysokoškolských študentov študujúcich na vysokých školách v Slovenskej republike. Zber údajov prebiehal kvantitatívnym spôsobom prostredníctvom vopred pripraveného dotazníka. Oslovili sme 200 vysokoškolských študentov, z toho 166 zodpovedalo zadané otázky. Kritériom výberu vysokoškolského študenta do skúmaného súboru respondentov bolo štúdium na l'ubovol'nej vysokej škole $\mathrm{v}$ rámci Slovenskej republiky. Získané údaje sme analyzovali $\mathrm{v}$ štatistickom softvéri SPSS 20 využitím bivariačnej a multivariačnej analýzy údajov.

\section{Haptika vo vysokoškolskej edukácii optikou oslovených vysokoškolských študentov}

$\mathrm{Na}$ základe zamerania empirického skúmania stanovenej problematiky sústred'ujeme centrum pozornosti $\mathrm{k}$ zdôrazneniu interpretovania zaznamenaných empirických údajov. Zistovali sme, či oslovení vysokoškolskí študenti identifikujú počas priebehu vysokoškolského edukačného procesu vybrané spôsoby neverbálnej komunikácie vysokoškolského pedagóga. Tak ako sme už uviedli vyššie, zamerali sme sa na oblast' haptiky. Skúmali sme, či sa podl'a názorov respondentov vysokoškolský pedagóg počas vedenia prednášok, seminárov alebo cvičení dotýka časti tváre - svojich vlasov, a či zvolená oblast' haptiky závisí od pohlavia vysokoškolského pedagóga. Zaznamenané zistenia sú zobrazené v nižšie uvedenej tabul'ke (Tabul'ka 1). 
Tabul'ka 1 Pohlavie pedagóga a haptika (dotyky vlasov) počas priebehu prednášok v rámci vysokoškolského edukačného procesu

\begin{tabular}{|c|c|c|c|c|c|}
\hline \multirow{2}{*}{\multicolumn{2}{|c|}{$\begin{array}{c}\text { Haptika (dotyky vlasov) } \\
\text { u vysokoškolského } \\
\text { pedagóga }\end{array}$}} & \multicolumn{4}{|c|}{ Pohlavie pedagóga } \\
\hline & & \multirow{2}{*}{$\begin{array}{l}\text { neodpovedal } \\
1 \\
\end{array}$} & \multirow{2}{*}{$\begin{array}{l}\text { muž } \\
12\end{array}$} & \multirow{2}{*}{$\begin{array}{l} \\
\\
\text { žena } \\
7\end{array}$} & \multirow{2}{*}{$\begin{array}{l}\text { spolu } \\
20\end{array}$} \\
\hline neodpovedal & početnost' & & & & \\
\hline & $\%$ & 0,6 & 7,2 & 4,2 & 12,0 \\
\hline \multirow[t]{2}{*}{ nie } & početnost' & 1 & 6 & 15 & 22 \\
\hline & $\%$ & 0,6 & 3,6 & 9,0 & 13,3 \\
\hline \multirow[t]{2}{*}{ skôr nie } & početnost' & 10 & 33 & 38 & 81 \\
\hline & $\%$ & 6,0 & 19,9 & 22,9 & 48,8 \\
\hline \multirow[t]{2}{*}{ skôr áno } & početnost' & 1 & 7 & 22 & 30 \\
\hline & $\%$ & 0,6 & 4,2 & 13,3 & 18,1 \\
\hline \multirow[t]{2}{*}{ áno } & početnost' & 0 & 0 & 6 & 6 \\
\hline & $\%$ & 0,0 & 0,0 & 3,6 & 3,6 \\
\hline \multirow{2}{*}{$\begin{array}{l}\text { neviem } \\
\text { posúdit' }\end{array}$} & početnost' & 2 & 3 & 2 & 7 \\
\hline & $\%$ & 1,2 & 1,8 & 1,2 & 4,2 \\
\hline \multirow[t]{2}{*}{ spolu } & početnost' & 15 & 61 & 90 & 166 \\
\hline & $\%$ & 9,0 & 36,7 & 54,2 & 100 \\
\hline
\end{tabular}

Na základe údajov vo vyššie uvedenej tabul'ke môžeme skonštatovat', že u pedagógov mužského pohlavia jednoznačne nezaznamenalo $3,6 \%$ respondentov skúmaný prejav haptiky - dotýkanie sa vlasov počas priebehu edukačného procesu. Takmer $20 \%$ opýtaných skôr neeviduje ako eviduje skúmaný prejav haptiky - dotýkanie sa vlasov medzi pedagógmi - mužmi v rámci vysokoškolskej edukácie. $\mathrm{Na}$ druhej strane upozorn̆ujeme na zaznamenané odpovede 13,3\% opýtaných, ktorí vo svojich odpovediach uviedli, že vysokoškolské pedagogičky sa v rámci realizácie prednášok počas vysokoškolského edukačného procesu skôr dotýkajú ako nedotýkajú svojich vlasov. Okrem toho $3,6 \%$ opýtaných vysokoškolských študentov jednoznačne poukázalo na prítomnost' skúmaného prejavu haptiky dotýkania sa svojich vlasov vysokoškolskými pedagogičkami v rámci vedenia vysokoškolských prednášok, seminárov alebo cvičení. Skúmaný prejav haptiky - dotýkanie sa vlasov počas priebehu vysokoškolského edukačného procesu je podl'a nášho názoru možné viac identifikovat' u vysokoškolských pedagogičiek ako u vysokoškolských pedagógov z toho dôvodu, že uvedený prejav neverbálnej komunikácie predstavuje častý zlozvyk pozorovatel'ný najmä u ženského pohlavia.

Identifikovaním vzájomnej závislosti medzi vybranou oblast'ou haptiky a pohlavím vysokoškolského pedagóga je možné následne analyzovat' zaznamenané zistenia aj prostredníctvom multivariačnej analýzy údajov. Prehl'adné zaznamenanie výsledkov multivariačnej analýzy údajov znázorňujeme na nižšie uvedenej korešpondenčnej mape (Graf 1). Na uvedenom grafe môžeme sledovat' vyjadrenie odpovedí oslovených vysokoškolských študentov poukazujúcich na prevažujúce identifikovanie

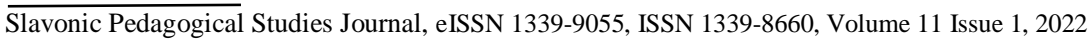


haptiky - dotýkania sa vlasov počas realizácie vysokoškolského edukačného procesu u vysokoškolských pedagogičiek v porovnaní s vysokoškolskými pedagógmi. Grafické znázornenie zaznamenaných údajov nášho skúmania na korešpondenčnej mape prehl'adným spôsobom naznačuje závislost' vybranej oblasti haptiky - dotýkanie sa vlasov od pohlavia vysokoškolského pedagóga.

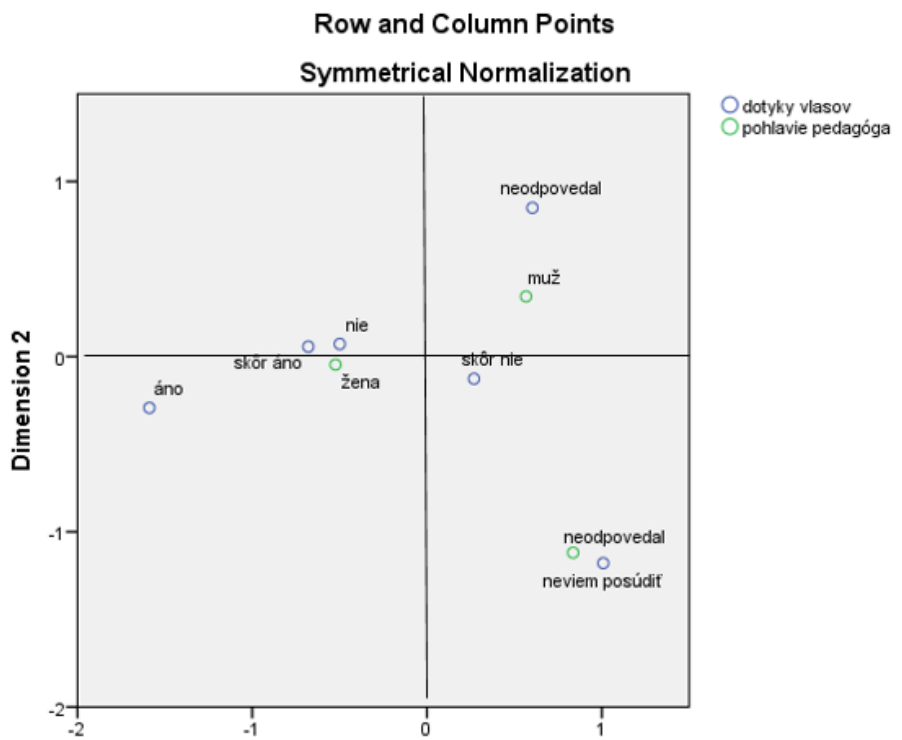

\section{Graf 1 Korešpondenčná mapa}

\section{Záver}

Pedagogická komunikácia predstavuje neoddelitel'nú súčast' vysokoškolského edukačného procesu. Vo vysokoškolskej edukácii dochádza k interakciám medzi vysokoškolským pedagógom a vysokoškolskými študentmi, ktoré sú v mnohých prípadoch založené na rôznych spôsoboch komunikácie či už verbálneho, ale aj neverbálneho charakteru.

$\mathrm{V}$ predkladanej štúdii teoreticko-empirického charakteru sme sa $\mathrm{v}$ teoretickej časti zamerali na vymedzenie pedagogickej komunikácie ako špecifického druhu sociálnej komunikácie. Pedagogickú komunikáciu vnímame ako sociálny jav prebiehajúci $\mathrm{v}$ edukačnom procese, ktorý je realizovaný prostredníctvom slovného, ale aj mimoslovného vyjadrovania sa. V súvislosti so sústredením centra pozornosti v rámci nášho d’alšieho analyzovania sme upozornili najmä na podstatu a význam neverbálnej komunikácie. Práve mimoslovný spôsob vyjadrovania sa považujeme za spôsob komunikácie odzrkadlujúci spravidla pravdivejšie a úprimnejšie ponímanie komunikovanej skutočnosti.

Neverbálna komunikácia tvoriaca súčast' pedagogickej komunikácie predstavuje súčast' aj vysokoškolského edukačného procesu. Z dôvodu širokého rozsahu oblasti neverbálnej pedagogickej komunikácie sme sa 
v empirickej časti predkladanej štúdie zamerali na skúmanie postojov a názorov oslovených vysokoškolských študentov dotýkajúcich sa prepojenia pedagogickej komunikácie vo vysokoškolskom edukačnom procese s oblast'ou haptiky. Haptiku považujeme za významnú súčast' neverbálnej komunikácie. Uvedené oblast’ neverbálnej komunikácie vymedzuje spôsoby dotykov počas priebehu komunikačného procesu. Ked’že sme v oblasti haptiky identifikovali niekol'ko spôsobov dotykov dotvárajúcich pedagogickú komunikáciu aj vo vysokoškolskom edukačnom procese, skúmali sme, či oslovení vysokoškolskí študenti vnímajú, že by sa vysokoškolský pedagóg dotýkal svojich vlasov počas priebehu prednášok, seminárov alebo cvičení. Na základe výsledkov bivariačnej a multivariačnej analýzy zaznamenaných údajov prostredníctvom štatistického softvéru SPSS 20 môžeme skonštatovat', že oslovení vysokoškolskí študenti identifikovali počas priebehu vysokoškolského edukačného procesu skúmaný prejav haptiky v rámci neverbálnej komunikácie prevažne u vysokoškolských pedagogičiek. Uvedené zistenie zdôvodňujeme najmä skutočnost'ou, že u ženského pohlavia je spomenutý prejav neverbálnej komunikácie vel'mi frekventovaný aj v každodenných interakciách realizovaných okrem vysokoškolského edukačného procesu. Dotyky tvárovej časti, konkrétne dotyky vlasov tak predstavujú určitým spôsobom zvyk, ktorého pretrvávanie spravidla neindikuje žiadne d’alšie subjektívne ponímanie realizácie edukačného procesu u vysokoškolského pedagóga.

Ked’že považujeme pedagogickú komunikáciu vo vysokoškolskom edukačnom procese za nezanedbatel'nú súčast' procesov výchovy a vzdelávania vysokoškolských študentov, tak upozorňujeme, že je potrebné aj d'alšie skúmanie uvedenej oblasti. Závery nášho skúmania naznačujú, že v rámci d’alšieho skúmania jednotlivých spôsobov neverbálnej komunikácie vysokoškolského pedagóga a vysokoškolských študentov by bolo vhodné vypracovat' ucelenejšiu analýzu spôsobov neverbálnej komunikácie, ktoré sú podl'a nášho názoru rovnako neoddelitel'nou súčast'ou vysokoškolského edukačného procesu.

\section{Bibliographic references}

Danek, J. (2014). Pedagogicka komunikacia na vysokej skole. Trnava: Univerzita sv. Cyrila a Metoda v Trnave. ISBN 978-80-8105-614-7.

Danilevskaya, N.V. et all. (2021). Cultural speech characteristics of the sounding world: A critical look at modern television speech. XLinguae 14 (2), pp 39-51. ISSN 1337-8384.

Gadusova, Z., Haskova, A., \& Ravettova, R. (2021). Methodological aspects of online forms of teaching. Journal of Education Culture and Society. No. 2 pp 139-152. ISSN 2081-1640.

Gavora, P. (2005). Ucitel a ziaci v komunikacii. Brno: Paido, ISBN 80-7315104-9.

Hasajova, L., Porubcanova, D., \& Bilcik, A. (2020). Vybrane kapitoly z pedagogickej komunikacie v odbornom vzdelavani. Dubnica nad Vahom: DTI. ISBN 978-80-8222-051-8. 
Klinckova, J. (2011). Neverbalna komunikacia alebo komunikujeme len slovami. Banska Bystrica: Univerzita Mateja Bela v Banskej Bystrici. ISBN 978-80-557-0168-4.

Kormanovicova, K. \& Halakova, Z. (2008). Neverbálna komunikácia v pedagogickej práci učitel’a. E-Pedagogium 8 (4), pp 59-66. ISSN 12137758.

Noskova, I. (2019). Umenie komunikacie. Bratislava: Metodickopedagogicke centrum, ISBN 978-80-565-1441-2.

Prucha, J. (2013). Moderni pedagogika. Praha: Portal, ISBN 978-80-2620456-5.

Samorodova, E.A., Belyaeva, I.G. \& Bakaeva, S.A. (2021). Analysis of communicative methods effectiveness in teaching foreign languages during the coronavirus epidemic: distance format. XLinguae 14 (1), pp 131-140. ISSN 1337-8384.

Seben Zatkova, T. a kol. (2015). Vybrane kapitoly z vysokoskolskej pedagogiky. Nitra: Slovenska polnohospdarska univerzita, ISBN 978-80-5521431-3.

Tomkova, V. (2010). Poziadavka komunikacnych zrucnosti pedagoga pri uplatnovani IKT vo vzdelavani. Nove technologie ve vyuce. Brno: Masarykova univerzita, pp. 1-4. ISBN 978-80-210-5333-5.

Mgr. Veronika Michvocíková, PhD.

Department of Pedagogy

University of St. Cyril and Methodius in Trnava

Nám. J. Herdu 2, 91701 Trnava

Slovakia

veronika.michvocikova@ucm.sk 